\title{
Research on the Influence of Financial Slack on Investment --- Based on Empirical Analysis of China's A-Share Listed Company in Manufacturing Industry
}

\author{
Jie Wang ${ }^{1}$ \\ ${ }^{1}$ College of Management, Shanghai University of Engineering Science, Shanghai, China \\ Correspondence: Jie Wang, College of Management, Shanghai University of Engineering Science, Shanghai, China. \\ E-mail: 1025249325@qq.com
}

Received: June 14, 2014

doi:10.5430/ijba.v5n4p52
Accepted: June 28, 2014

Online Published: July 3, 2014

URL: http://dx.doi.org/10.5430/ijba.v5n4p52

\begin{abstract}
This paper studies, taking China's A-share listed company in manufacturing industry as the object, how the investment is influenced by the financial slack and whether the influence is adjusted by the investment risk of new project. The conclusions are as follow: (1) The China's A-share listed companies in manufacturing industry' financial slack has a positive impact on the companies' future investment. (2) Under the high-risk investment of project, financial slack has a positive effect on the companies' future investment.
\end{abstract}

Keywords: financial slack, the scale of investment, investment risk of new project

\section{Introduction}

The relationship between the enterprises' development and investment is close. Investment decision is not only the main reason of the companies' growth and the important foundation of the companies' growth of the future cash flow, but also the starting point of the corporate financial decision. The investment activities of China's A-share listed company in manufacturing industry have obvious industry characteristic: its scale of investment is larger and recovery period of investment is longer than the other. Although many previous scholars both at home and abroad studied the factors of influence on the scale of investment, few scholars studied it in financial redundant angle. Based on the financial redundant angle to study the scale of investment of China's A-share listed company in manufacturing industry, this paper has certain research significance.

Scholars both at home and abroad have long been concerned about financial redundancy problem. In 1963 Cyert \& March's book - 'the corporate behavioral theory', it first proposed the concept of organization redundancy, namely the difference between resources obtained the internal small groups of organization and resources of maintaining organization's requirements. Then the foreign scholars constantly improved this concept, of which Bourgeois' $s$ (1981) concept of organization redundancy was the most accepted by later generations. He pointed out that organization redundancy is the enterprise's actual or potential idle resources, it enables the organization to successfully deal with pressure from internal or external and adapt to the need of the external environment change in strategy. Financial redundancy is an important part of the organization redundancy, the concept of organization redundancy provides a theoretical basis for understanding financial redundancy. In his discussion of the pecking order theory, Myers (1984) first mentioned the concept of financial slack, it refers to enterprise' the cash and cash equivalents and the risk-free liabilities. Financial slack was defined as more than the liquidity of existing enterprise' operation and debt need and risk-free lending capacity and it can make companies pursue freely investment opportunities which have positive net present value and don't worry about risk issue (Zhong Heping, Zhang Xumei and Fang Runsheng, 2008). Based on the definition of financial redundant, many scholars both at home and abroad divided the financial redundant into categories from different angles. In the study of relationships between finance redundant, executive team strategic behavior and political behavior, Bourgeois \& Singh (1983) divided the financial redundancy into three categories: available financial redundancy, potential financial redundancy and recoverable financial redundancy. Available financial redundancy which is the financial resource refers not to be engaged into the organization's specific tasks; recoverable financial redundancy which is the financial resource refers to have been absorbed into an organization' concrete operation procedure, but the organization can obtain it again by redesigning, 
such as the excessive cost, marketing fees, and management fees, and so on; the potential financial redundancy can be obtained by borrowing from external resources. Also some scholars divided financial redundant into precipitating redundancy and non-precipitating redundancy. The flexibility and mobility of precipitation redundancy is low, including excessive management fees, financial fees and marketing fees, and so on. These redundant resources have very viscous and transforming them into the other demands needs a long time and high conversing cost. Non-precipitating redundancy usually includes cash, cash equivalents and other current assets. Compared with precipitating redundancy, non-precipitating redundancy have high flexibility and mobility, can be used by managers quickly and have the low conversing cost (Latham SF, \& Braum MR, 2008, Wan W.P \& Yiu D.W, 2009).

Based on the above theory, this paper defines the concept of financial redundant as a combination of more than the liquidity of existing enterprises' operation and debt need (such as cash and cash equivalents) and enterprises' reserve debt capacity (such as banks grant the enterprise credit), the latter is a buffer of enterprises' funds needed. It is the major financial resources to meet business' low-risk financial needs. The extent of financial redundancy may reflect the degree of relaxation in the chain of corporate finance funds.

\section{Literature Review and Research Assumption}

\subsection{The Effect of Financial Redundancy on the Investment Scale}

The amount of financial slack resources influences the companies' investment decision. The main purpose of holding redundant resources enables companies to grasp good investment opportunities in the future better. There are a lot of literature research about relationships between the high cash holdings and investments. When the enterprise holds a large amount of cash assets, it will inevitability appear the phenomenon of excessive investment (Stulz, 1990). The excessive cash held by companies has insensitive to the investment and opportunities of growth and their amount of investment could be far greater than the amount of normal cash held by the companies (Shin \&Kim's, 2002). Corporates which held excessive cash have serious over-investment (Yang Xingquan et al., 2010). Taking China's agricultural listed companies between 2005 and 2009 as the sample, empirical studies found that the China's agricultural listed companies which held high cash invested more than the agricultural companies lack of cash holdings (Wu Wei, 2011). These studies confirm the high cash holdings can cause excessive investment. Research on enterprise's ability of reserving liabilities and financial redundant is less. Banks credit leads to the excessive investment, as long as within the scope of the credit, the enterprise's loan interest rate will not increase along with the loan, so as to encourage enterprises to continuously invest in new projects (Duan \&Yoon, 1993). The shortage of financial redundancy will lead to inadequate investment; while the excessive financial redundancy will lead to excessive investment (Smith \& Kim, 1994). Taking China's listed companies as the research sample and empirical studies have found that financial redundancy has a positive effect on companies' future investment (Bi Xiaofang \& Jiang Baoqiang, 2012).

The abundant of internal capital can reduce the dependence of external high-cost funds. In addition to hold the liquidity, enterprises consider the future financing constraints and will reserve a portion of the debt capacity present which will enable the enterprises to raise debt capital at relatively low cost. The accumulation of financial slack motivated by financial flexibility, enterprise will use it to meet the future demand of investment. For their own interests, enterprise' managers will maintain financial redundancy. The financial redundancy will be used to expand the future investment, so as to expand the managers' control scale of enterprise assets. As a result, we get the following assumption:

Assumption 1: The company's financial redundancy has a positive effect on the scale of investment.

\subsection{The Influence of Investment Risk of Project on Correlation of Financial Redundant and Investment}

Investment risk of project is an important factor that must be considered when the companies make investment decisions. When investment risk of project is low and enterprises have sufficient financial slack resources, enterprises will be committed to the expansion of investment and obtain profits; when investment risk of project is high, even if the enterprises have sufficient financial slack resources, they will not expand the scale of investment. As a result, we get the following assumption:

Assumption 2: The companies' investment risk of new project has a reverse impact on correlation of financial redundant and investment.

\section{Data, Variables and Model}

\subsection{Sample Selection and Data Sources}

In this paper, the China's A-share listed companies in the manufacturing industry' data from Shanghai and Shenzhen 
stock exchanges is used for empirical analysis. The reason for choosing the manufacturing industry is that manufacturing enterprises have higher degree of dependence on all kinds of resources in the process of production and operation and they are an important component of China's industry (as of 2005 December, domestic listing corporation amounted to 1573 , of which listed companies in the manufacturing industry have 909 homes, the proportion nearly as high as $60 \%$ ). They play a decisive role in the whole system of national economy and have a strong representation. We take the year 2009 as the data' window and select data from 2006 to 2012 .We screen data according to the following principles: (1) Considering the influence of abnormal value, we exclude the all companies of which annual asset-liability ratio is more than 1 and the all companies which continue loss (PT, ST (Note 1)). (2) Because this article's research variables are many and not all companies' information is complete, we also excluded them. Through the above screening, finally there are 458 listed companies. The data used in the paper comes from Shenzhen Tai'an CSMASR financial database, http://finance.sina.com.cn, http://www.sse.com.cn and http://www.szse.cn. The data is processed by the EXCEL2007 form and the SPSS20.0 statistics software.

\subsection{Study Variables}

The studied variables involved this paper as follows:

1) Be explained variable

The scale of investment. Chinese scholars mainly use two alternative variables to study the investment activities of enterprises:(1) Using the added value of fixed assets and long term investments, etc. replaces the investment expenditure;(2)Using purchase payment of fixed assets, intangible assets and other long-term assets in the cash flow statement replaces the investment expenditure. This article refers to Tong Pan \& Liu Zhengfei's (2005) measurement method of the investment scale (that is the investment-the proportion of capital stock $(\mathrm{I} / \mathrm{K})$ ). Investment $(\mathrm{I})=$ annual change of original value of fixed assets, projects under construction and engineering material, namely their balance by the end of the year minus the beginning of the year; capital stock $(\mathrm{K})=$ total asset at the beginning of the year. In order to eliminate the effect of the scale of enterprise, we use the relative number between investment and capital stock as the scale of investment.

\section{2) Explanatory variables}

Financial redundancy. On the financial redundancy' classification, many scholars divided the financial redundancy into available financial redundancy, potential financial redundancy, recoverable financial redundancy, while some scholars divided financial redundancy into precipitating redundant redundancy and non-precipitating redundant redundancy. Through the analysis, the above two classification method of financial redundant is the same in fact and non-precipitating financial redundancy mainly consists of available financial redundancy and potential financial redundancy. This paper argues that the available financial redundancy and potential financial redundancy can be used as an enterprise's ability to cope with future environmental change and help organizational innovation. Scholars at home and abroad mainly measured financial redundancy through two ways as follows: one is the questionnaire survey method, the other method is using specific financial indicators. Considering that most scholars used financial indicators to measure financial redundancy, compared with the method of questionnaire, and financial index is more stable, this article also uses financial indicators to measure the financial redundancy. On measurement of available financial redundancy, Martinez \& Artz (2006) used liquidity ratio index, while some scholars used quick ratio index; On measurement of potential financial redundancy, Martinez \& Artz (2006) used the debt to equity ratio, while some scholars used debt to asset ratio. According to Daniel et al.'s (2004) research, most scholars mainly used the liquidity ratio and equity ratio to measure respectively the available financial redundancy and potential financial redundancy. Therefore, this article also uses this measurement method. Using the current ratio measures available financial redundancy; Using equity ratio measures potential financial redundancy; And the sum of them represents the financial redundancy level, expressed with symbols Slack, namely financial redundancy (Slack) $=$ current ratio + equity ratio.

\section{3) Moderator variable}

The investment risk of new project. This article refers to Tong Pan \& Liu Zhengfei's (2005) measurement methods of the investment risk of new project. Using the difference of fluctuation of companies' EBIT in 2009 years ago, after three years indicates the relative size of the year 2009' the investment risk of new project and enterprise risk before the new investment, written as $\Delta \mathrm{CV}$. $\triangle \mathrm{CV}=\mathrm{CV}_{2010-2012}-\mathrm{CV}_{2006-2008}, \mathrm{CV}_{2006-2008}$ and $\mathrm{CV}_{2010-2012}$ respectively represent sample companies' 2006-2008 and 2010-2012 EBIT absolute value of variation coefficient. If the $\Delta \mathrm{CV}>0$, the investment risk of new project is bigger, because after the implementation of the project, the enterprise's risk will increase overall; on the contrary, if the $\Delta \mathrm{CV}<0$, the investment risk of new project is smaller, because after the 
implementation of the project, the enterprise's risk will fall overall. We use the virtual variable PR to represent the investment risk of new project, if $\Delta \mathrm{CV}<0$, the PR takes 0 ; if $\Delta \mathrm{CV}>0$, then PR takes 1 .

4) Control variables

A lot of the existing literature suggests that there are many factors which can affect the level of investment, such as corporate cash flow, the proportion of the first shareholder and corporate size, etc. In this paper, the proportion of the first shareholder and the company's size be used as control variables.

a) The proportion of the first shareholder $\left(\mathrm{N}_{1}\right)$. We use the shareholding ratio of the first major shareholder of listing corporation to measure it.

b) Company's size (lnasset). At present, there are two main methods to measure the companies' size: (1) Some use natural logarithm of the companies' operating income to measure it; (2) Others use natural logarithm of the companies' total assets to measure it. The first method cannot fully cover all the resources of enterprises. So, we use the natural logarithm of the enterprises' total assets to measure the companies' size.

Based on the above analysis, the variables are defined as shown in Table 1

Table 1. List of study variables

\begin{tabular}{|c|c|c|c|}
\hline $\begin{array}{l}\text { Variable } \\
\text { Types }\end{array}$ & Variable Name & Variable Code & Variable Definition and Description \\
\hline $\begin{array}{l}\text { Be explained } \\
\text { variables }\end{array}$ & $\begin{array}{l}\text { The scale of } \\
\text { investment }\end{array}$ & $\mathrm{I} / \mathrm{K}$ & $\begin{array}{l}\mathrm{I}=\text { the sum of original value of fixed } \\
\text { assets, projects under construction and } \\
\text { engineering materials at the end of the } \\
\text { year -the sum of original value of fixed } \\
\text { assets, projects under construction and } \\
\text { engineering materials at the beginning } \\
\text { of the year; } \mathrm{K}=\text { total assets at the } \\
\text { beginning }\end{array}$ \\
\hline $\begin{array}{l}\text { Explanatory } \\
\text { variables }\end{array}$ & $\begin{array}{l}\text { Financial } \\
\text { redundancy }\end{array}$ & Slack & Current ratio plus debt to equity ratio \\
\hline $\begin{array}{l}\text { Moderator } \\
\text { variable }\end{array}$ & $\begin{array}{l}\text { The investment risk } \\
\text { of new project }\end{array}$ & PR & $\begin{array}{l}\text { If } \Delta C V<0 \text {, the PR takes } 0 \text {; If } \Delta C V> \\
0, \text { then PR takes } 1 .\end{array}$ \\
\hline \multirow{2}{*}{$\begin{array}{l}\text { Control } \\
\text { variables }\end{array}$} & Company's size & lnasset & The natural logarithm of total assets \\
\hline & $\begin{array}{l}\text { The proportion of } \\
\text { the first shareholder }\end{array}$ & $\mathrm{N}_{1}$ & $\begin{array}{l}\text { The shareholding ratio of the first } \\
\text { major shareholder of listing } \\
\text { corporation }\end{array}$ \\
\hline
\end{tabular}

\subsection{Model Design}

3.3.1 To test the influence of financial redundancy on the level of corporate investment, we establish the model (1). Considering that the influence of financial redundancy on the level of corporate investment is delay, financial slack here uses the data lagged one year (the same below). If financial redundancy's (Slack $i, t-1$ ) coefficient $\alpha_{1}$ is significantly greater than zero, showing that financial redundancy can produce a positive influence on investment in the future, the assumption 1 establishes.

$$
I_{i, t} / K_{i, t-1}=\alpha_{0}+\alpha_{1} \text { Slack }_{i, t-1}+\alpha_{2} \text { Inasset }_{i, t}+\alpha_{3} N_{l i, t}+\varepsilon
$$

3.3.2 According to the assumption 2, on the basis of the model (1), we add the investment risk of new project (PR) and interaction of the investment risk of new project and financial redundant ( $\mathrm{PR} *$ Slack), so as to establish the model (2). In the model (2), if the interaction term's (PR * Slack) coefficient is significantly negative, showing that the investment risk of new project have a negative effect on correlation of financial redundant-investment, the assumption 2 establishes.

$$
I_{i, t} / K_{i t-1}=\alpha_{0}+\alpha_{1} \text { Slack }_{i, t-1}+\alpha_{2} P R+\alpha_{3} P R * \text { Slack }_{i, t-1}+\alpha_{4} \text { Inasset }_{i, t}+\alpha_{5} N_{I i, t}+\varepsilon
$$




\section{The Results of the Study and Analysis}

\subsection{Descriptive Test Results and Analysis}

Firstly, as shown in Table 2, this article makes a descriptive test on China's A -share listing corporation in the manufacturing industry. The test results show that the difference between the maximum and minimum values of all the variables is large, indicating there is a large difference between the different enterprises. China's A-share listed companies in the manufacturing industry' annual average growth rate of investment level is about $5.57 \%$, but different enterprises have bigger difference: the fastest reaches 0.5 times, while some companies experience negative growth. The sample's mean is significantly higher than the median, so the growth rate of investment level in whole is between $3 \%-5 \%$. The level of financial redundancy's mean is 0.5759 , the standard deviation is 2.0449877 , and the difference between the minimum and maximum values is 13.5926. Visibly, the difference between the sample enterprises' the level of financial redundant is obvious. The investment risk of new project's mean is -0.136631 and the standard deviation is 1.6449910 , indicating that the risks faced by manufacturing enterprises in whole is lower but the different enterprises have a big difference. The average shareholding ratio of the first major shareholder of listing corporation is up to $34.6529 \%$ and the standard deviation is $12.98614 \%$, indicating that the China's A-share listing corporation in manufacturing industry' equity is still relatively concentrating and shareholders have absolute rights of control, resulting in the situation of 'a single big holder'. The size of the sample companies' mean is 21.671334 and the standard deviation is1.0076431, showing that the China's A-share listing corporation in manufacturing industry's size is big in whole and the differences of different enterprises is various.

Table 2. Descriptive test results

\begin{tabular}{lllllll}
\hline & $\mathrm{N}$ & $\begin{array}{l}\text { Minimum } \\
\text { value }\end{array}$ & $\begin{array}{l}\text { Maximum } \\
\text { value }\end{array}$ & Mean & Median & $\begin{array}{l}\text { Standard } \\
\text { deviation }\end{array}$ \\
\hline $\mathrm{I} / \mathrm{K}$ & 458 & $-9.4889 \%$ & $50.9441 \%$ & $5.570412 \%$ & $3.405061 \%$ & $8.3583427 \%$ \\
\hline Slack & 458 & 0.5759 & 14.1684 & 2.860355 & 2.262555 & 2.0449877 \\
\hline $\mathrm{PR}$ & 458 & -9.1567 & 8.8044 & -0.136631 & -0.070500 & 1.6449910 \\
\hline $\mathrm{N} 1$ & 458 & $10.38 \%$ & $67.50 \%$ & $34.6529 \%$ & $33.5850 \%$ & $12.98614 \%$ \\
\hline lnasset & 458 & 19.3085 & 24.6654 & 21.671334 & 21.543800 & 1.0076431 \\
\hline
\end{tabular}

\subsection{Regression Test Results and Analysis}

Table 3. Regression test results

\begin{tabular}{lllll}
\hline & \multicolumn{1}{c}{ Model(1) } & \multicolumn{3}{c}{ Model(2) } \\
\cline { 3 - 5 } & & All samples & \multicolumn{1}{c}{ PR=0 } \\
\hline Constant & -54.657 & -55.051 & -35.471 & -88.375 \\
& $\left(-6.564^{* * *}\right)$ & $\left(-6.554^{* * *}\right)$ & $\left(-3.270^{* *}\right)$ & $\left(-6.847^{* * *}\right)$ \\
\hline Slack & 0.475 & 0.295 & 0.190 & 1.280 \\
& $\left(2.557^{* *}\right)$ & $(1.394)$ & $(0.867)$ & $\left(3.559^{* * *}\right)$ \\
\hline PR & & $-1.724(-1.246)$ & & \\
\hline PR*Slack & & $0.793\left(1.879^{*}\right)$ & & 0.064 \\
\hline $\mathrm{N}_{1}$ & 0.070 & 0.067 & 0.065 & $(1.401)$ \\
& $\left(2.434^{* *}\right)$ & $\left(2.316^{* *}\right)$ & $\left(1.754^{*}\right)$ & 4.090 \\
\hline lnasset & 2.604 & 2.644 & 1.761 & $\left(6.845^{* * *}\right)$ \\
\hline $\mathrm{R}^{2}$ & $\left(6.813^{* * *}\right)$ & $\left(6.888^{* * *}\right)$ & $\left(3.557^{* * *}\right)$ & 0.243 \\
\hline Adj- $\mathrm{R}^{2}$ & 0.117 & 0.124 & 0.064 & 0.231 \\
\hline $\mathrm{D} . \mathrm{W}$. & 0.111 & 0.115 & 0.053 & 2.240 \\
\hline $\mathrm{F}$ & 1.848 & 1.856 & 1.843 & 19.929 \\
(sig.) & 20.040 & 12.854 & 6.024 & $(0.000)$ \\
\hline $\mathrm{N}$ & $(0.000)$ & $(0.000)$ & $(0.001)$ & 190 \\
\hline
\end{tabular}


Note: In the Table 3, the first item' data is relative variable coefficient estimates and T-value is shown in brackets.* indicates significant level of $\mathrm{T}$-value in regression analysis (two tailed).*,**,*** represent respectively significant level of T-value: $10 \%, 5 \%, 1 \% . \mathrm{N}$ is the number of samples. In model 2, PR represents the investment risk of new projects. According to the PR, the sample firms will be divided into two categories: $\mathrm{PR}=0$ indicates the investment risk of new projects is relatively low (namely after the implementation of the new project, the enterprise's risk will fall overall)and it calls the enterprises of low-risk project; $P R=1$ indicates the investment risk of new projects is high (namely after the implementation of the new project, the enterprise's risk will increase overall)and it calls the enterprises of high-risk project. According to the Table 3, the test results of the regression shows model (1) and the model (2) 's DW are all close to 2 and the linear correlation between each variables has no apparent significant.

Assumption 1and assumption 2's test results were listed in Table 3. From the full sample's test results of model (1), the coefficient of financial redundancy for the investment scale is 0.475 and it is significantly greater than zero at the $5 \%$ level, indicating assumption 1 establishes. It shows that China's A-share listed companies in manufacturing industry's financial redundancy policy in whole has a significant positive impact on companies' the level of investment next year. In the face of good investment opportunities, keeping financial redundancy makes enterprises grasp them actively, so as to improve corporate earnings.

In model (2), the regression coefficient of interaction of investment risk of new project and financial redundant (PR * Slack) is significant positive correlation at the $10 \%$ level, in contrast to the assumption 2 , so the assumption 2 doesn't establish. The possible reason is that there are agency conflicts between managers and creditors. When making investment decisions and the companies' project of new investment has higher risk, even if the project of new investment's NPV is less than zero, the enterprise has adequate financial redundant resources and the manager may also invest the project for the interests of shareholders. Because the implementation of the project leads to increase the risk of enterprise' bankruptcy, creditors' wealth may be transferred to the shareholders. This will cause the shareholders to invest the project which NPV is less than zero, resulting in the phenomenon of over-investment. When the interest between managers and shareholders is consistent and the other conditions (such as debt ratio, business risk) is certain, the new project risk is bigger, the excessive investment is more serious (Parrino \&Weisbach's, 1999). In order to verify this interpretation, we do a regression analysis by divided the sample firms into two categories (respectively, firms of low-risk project and firms of high-risk project), according to the PR. The regression results show that this explanation has been verified. When making decisions of investment, due to the presence of agency conflicts, firms of high-risk project's managers will cause over-investment.

\section{Stability Test}

Next, by changing the values of the explanatory variables, we do a stability test for these empirical results. Instead of the financial redundancy which is equal to the current financial ratio and debt to equity ratio through the financial redundancy which is equal to the speed ratio and debt to equity ratio, we do a regression analysis. In table 4, the regression' results again prove that the relationship between enterprise financial redundancy and the scale of

investment is significant positive correlation and under enterprises of the high-risk project, the correlation of financial redundancy and the scale of investment is significant positive. This agrees with the previous test results. 
Table 4. Stability test results

\begin{tabular}{lllll}
\hline & & \multicolumn{3}{c}{ Model(2) } \\
\cline { 3 - 5 } & & All samples & \multicolumn{1}{c}{ PR=0 } & \multicolumn{1}{c}{ PR=1 } \\
\hline Constant & -54.746 & -55.284 & -35.918 & -88.085 \\
& $\left(-6.598^{* * *}\right)$ & $\left(-6.607^{* * *}\right)$ & $\left(-3.322^{* *}\right)$ & $\left(-6.850^{* * *}\right)$ \\
\hline Slack & 0.538 & 0.351 & 0.240 & 1.449 \\
& $\left(2.682^{* *}\right)$ & $(1.547)$ & $(1.023)$ & $\left(3.608^{* * *}\right)$ \\
\hline PR & & $-1.549(-1.190)$ & & \\
\hline PR*Slack & & $0.890\left(1.905^{*}\right)$ & & 0.062 \\
\hline $\mathrm{N}_{1}$ & 0.071 & 0.067 & 0.065 & $(1.375)$ \\
& $\left(2.448^{* *}\right)$ & $\left(2.318^{* *}\right)$ & $\left(1.769^{*}\right)$ & 4.089 \\
\hline lnasset & 2.611 & 2.654 & 1.779 & $\left(6.854^{* * *}\right)$ \\
\hline $\mathrm{R}^{2}$ & $\left(6.842^{* * *}\right)$ & $\left(6.927^{* * *}\right)$ & $\left(3.598^{* * *}\right)$ & 0.245 \\
\hline Adj- ${ }^{2}$ & 0.118 & 0.126 & 0.065 & 0.232 \\
\hline D.W. & 2.112 & 0.116 & 0.054 & 2.251 \\
\hline $\mathrm{F}$ & 20.284 & 2.037 & 1.844 & 20.073 \\
$($ sig. & $(0.000)$ & 13.029 & 6.128 & $(0.000)$ \\
\hline $\mathrm{N}$ & 458 & $(0.000)$ & $(0.000)$ & 190 \\
\hline
\end{tabular}

\section{Conclusion, Suggestions and Deficiencies}

In this paper, we take China's A-shares listing Corporation in manufacturing industry as the object of study. From financial redundancy perspective, we do an empirical analysis of the influential factors of investment scale of China's A-share listing corporation in manufacturing industry. The study found: (1) China's A-share listing corporation in manufacturing industry's financial redundancy policy has a significant positive impact on companies' investment level next year. Keeping financial redundancy makes enterprises more active to grasp the good investment opportunities. (2) In making investment decisions, the enterprises of high-risk project will appear the phenomenon of excessive investment.

The key of the strategic management of manufacturing enterprises lies in integrating resources and optimizing the allocation of resources. Financial redundancy is the material basis which makes the organization grasp investment opportunities and achieve the strategic adjustment. Enterprises should combine with their environment of system and business strategy to develop appropriate policies of financial redundancy. When the enterprises make investments and interest between managers and shareholders is consistent, even if higher risk of investments, companies will invest in the project and it will transfer the high risk to the creditor, resulting in damaging the interests of creditors. China's listed companies in manufacturing industry should strengthen internal management, improve the mechanism of balance and avoid blind investment made by managers and shareholders for their own interests, so as to protect the interests of creditors from harming.

This paper's shortages and problems needing further research mainly focus on the following aspects: 1) Because the data selection is too long and too complex and my level is limit, some index is only calculated by average of the companies' data each year. So it is too simple. 2) This paper's research is limit to the investment risk of new project influencing on the relationship of financial redundancy and the scale of investment, not in terms of research for corporate governance, which is the direction of the efforts in the future.

\section{References}

Bi, Xiaofang, \& Jiang, Baoqiang. (2012). Research on the influence of financial slack on investment - Based on agency costs and product market competition. Financial Policy and Behavior Research, (5), 98-106. 
Bourgeois, L.J, \& Singh, JV. (1983). Organizational slack and political behavior within top management teams. Proceedings of the Academy of Management, 2(3), 43-49. http://dx.doi.org/10.5465/AMBPP.1983.4976315

Bourgeois, L.J. (1981). On the Measurement of Organizational Slack. Academy of Management Review, 6(1), 29-39.

Daniel, F., Lohrke, F.T., Fornaciari C.J., \& Turner, R.A. (2004). Slack resources and firm performance: a meta-analysis. Journal of Business Research, 57(6), 565-574. http://dx.doi.org/10.1016/S0148-2963(02)00439-3

Duan, J., \& Yoon, S.H. (1993). Loan commitments, investment decisions and the signaling equilibrium. Journal of Banking and Finance, (17), 645-661. http://dx.doi.org/10.1016/0378-4266(93)90005-X

Latham, S.F., \& Braum, M.R. (2008). The performance implications of financial slack during economic recession and recovery: observations from the software industry (2001-2003). Journal of Management Issues, 20(1), $30-50$.

Martinez, R.J., \& Artz, K. (2006). An examination of firm slack and risk-taking in regulated and deregulated airlines. Journal of Managerial Issues, 18(1), 11-32.

Myers Steward. (1984). The Capital Structure Puzzle. Journal of Finance, 39(3), 575-592. http://dx.doi.org/10.2307/2327916

Parrino, R., \& M.S. Weisbach. (1999). Measuring investment distortions arising from stockholder bond-Holder conflicts. Journal of Financial Economics, (53), 3-42. http://dx.doi.org/10.1016/S0304-405X(99)00015-X

Shin, H.H., \& Kim, Y.H. (2002). Agency costs and efficiency of business capital investment evidence from quarterly capital expenditures. Journal of Corporate Finance, (8), 139-158. http://dx.doi.org/10.1016/S0929-1199(01)00033-5

Smith, R.L., \& Kim, J.H. (1994). The combined effects of free cash flow and financial slack on bidder and target stock returns. The Journal of Business, (67), 281-310. http://dx.doi.org/10.1086/296633

Stulz. (1990). Managerial discretion and optimal financing policies. Journal of Financial Economics, (26), 3-27. http://dx.doi.org/10.1016/0304-405X(90)90011-N

Tong, Pan, \& Lu, Zhengfei. (2005). Debt financing, the sources of debt, and the firms' investment behavior: Evidence from listed companies in China. Economic Research, (5), 75-84.

Wan, W.P., \& Yiu, D.W. (2009). From crisis to opportunity: environmental jolt, corporate acquisitions, and firm performance. Strategic Management Journal, 30(7), 791-801. http://dx.doi.org/10.1002/smj.744

Wu, Wei. (2011). Research on the impact of cash holdings' level on investment spending in China's agricultural listed companies: (Master's thesis). Inner Mongolia: the University of Inner Mongolia.

Yang, Xingquan, Zhang, Zhaonan, \& Wu, Haomin. (2010). The analysis of governance environment, the excess cash and excessive investment based on panel data of listed companies in our country. Nankai Management Review, 13(5), 61-69.

Zhong, Heping, Zhang, Xumei, \& Fang, Runsheng. (2008). The relationship between financial slack and firm performance. Modernization of Management, (5), 31-33.

\section{Note}

Note 1. According to the company law and the securities law' regulation, the PT company refers to the listed company which appear consecutive losses in three years, etc. and its shares will be suspended. ST company refers to the listed company of which shares be done special treatment by the exchange because of the company which appears consecutive losses in two years, losses in one year and the net assets below the nominal value or the major violations in business process, and so on. 